\title{
Building Community-Oriented Knowledges
}

Travis L. Wagner

University of South Carolina

Sarah Keeling

National Association for Campus Activities

Abstract: This article focuses on specific strategies faculty and staff can use to create knowledge-

oriented graduates. This means that we want our students and alumni to understand how their policies, procedures, and daily practice impact al/the people in their community. We posit that taking a student-centered approach, advocating for social justice issues, and offering service-learning experiences creates socially just, community-based, and praxis-informed alumni. It adheres to the Knowledge School tenet of "practitioner-informed" by offering practical strategies for those who work with LIS students.

Keywords: community, student-centered, service-learning, social justice

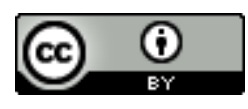

This is an Open Access article distributed under the terms of the Creative Commons Attribution 4.0 International License (http://creativecommons.org/licenses/by/4.0), which permits unrestricted use, distribution, and reproduction in any medium, provided the original work is properly cited. 
At the School of Library and Information Science, we want our graduates to go out into the field ready to contribute, to their places of employment and to the communities in which they are situated. We want these graduates to be user-focused, whether that user is a library patron or a data management company. We also want these graduates to be able to build partnerships, not only in the organization they work for, but also across institutions and industries. Finally, we want these graduates to have an outward gaze, to see beyond themselves, and to understand how policy and practice may affect historically oppressed or marginalized people.

This is a tall order for faculty and staff, who must also ensure that students meet the learning outcomes of the program through coursework and that the program meets multiple accreditation standards. While undergraduates often have the opportunities to get involved with activities and organizations that shed light on the world beyond the college campus, many graduate students do not. Most extracurricular activities at the graduate level involve professional development and many students work full-time, have families, and hold numerous responsibilities beyond school. Convincing an already overloaded student to take on more is a difficult task. Moreover, the expectation that students will encounter diversity in their prospective careers (particularly those going into librarianship) remains unlikely, as the field is one still heavily dominated by white, cisgender women (Hankins \& Juárez, 2016). In turn, programs must (and can) do several things to create the engaged alumni they are seeking by being student-centered, advocating for social justice issues, and offering service-learning experiences.

\section{Center the Student}

The term student-centered learning refers to a wide variety of educational programs, learning experiences, instructional approaches, and academic-support strategies that are intended to address 
the distinct learning needs, interests, aspirations, or cultural backgrounds of individual students and groups of students (Great Schools Partnership, 2014).

Student-centered programs put the focus on students and lets students know they are more than just a number. We must keep in mind the individuality of students and be aware of some of the academic and personal issues they may be facing while ensuring a program is effective and fair. We can do this by being ethical, personal, and empathetic. Policies and procedures that are in place or will be created must be applied fairly across the board. Clear, easily accessible policies and procedures that are available to everyone - students, faculty, and staff - help in this process. We must also take the time to understand students on a personal level, beyond the scope of the classroom. Many graduate students go through major life experiences while enrolled. We need to practice empathy as we relate to students.

Take as an example, a student transitioning genders. The state of South Carolina has a cumbersome process for all individuals attempting to change things like their gender and dead name (a term regularly used by trans, genderqueer and gender non-conforming folks to acknowledge a name they were given at birth). The individual attempting to legally confirm their transition must seek medical and psychological counsel before they are even allowed petition to have their name/gender changed and even if the individual were to properly complete the required paperwork they would remain beholden to the decision of a judge who can arbitrarily approve or deny such a request (National Center for Transgender Equality, 2017). While a student-centered program can hardly expedite the legal challenges present in transitioning within South Carolina, it can certainly aim to alleviate the microaggressions faced by trans- and gender- nonconforming communities by acknowledging (even if unofficially) the desired identity of students. Internally, a student-centered 
program would make procedures that allow students to transition within the school in a quick, comfortable, and comprehensive manner. To be clear, while these types of changes serve to aid a chronically oppressed group of individuals, the ability to quickly change names provides potential benefits to other groups such as persons changing their name upon marriage or divorce or a person who goes by a nickname not provided in legal documentation. In this way, student-centered programming shares in the mantra of Universal Design (Strangman, Rappolt, Rose, \& Meyer, 2002) wherein changes made for marginalized groups should become changes that reflect the needs of the collective, which can, in fact, benefit those with or without marginalized identities. A student-centered approach might imagine this as approaching programming from a group framework, while also incorporating for quick adjustments when necessary.

Another way to imagine how student-centered programming might operate is to ask a deceptively simple question. How do we make students not feel like a number? Some answers to this inquiry are fairly obvious. Respond to emails quickly. Be aware of your tone of voice on the phone speak as if you know them. Include students on committees, and take their feedback within committee work seriously.

Other answers are a bit more complex. An approach to programming that prioritizes the student works to address the demands of students entering a constantly evolving field in a manner that is proactive, as opposed to retroactive. This model invites direct student participation in the structuring of course content, internship opportunities, and, crucially, the narrative delivered to the school's outside stakeholders. As noted, the school promotes a philosophy of user-centered work and the easiest way for a student to understand how this operates is by being directly exposed to the value 
and joy felt when being cared for and earnestly being heard. Essentially, we are modeling behavior for our students. We want them to be user-focused when they graduate. They are our users.

Finally, a student-centered approach teaches students how to be resource ready. When graduates go out into the field, they will provide a variety of services to a variety of people. One person, nor one place, can have all the answers. To provide better service, a patron may have to be referred elsewhere. Likewise, on a college campus, not one office can meet all the needs a student may have. Resources on a college campus may include areas such as counseling services, writing centers, veterans services, disability services, etc. We can help connect students to these services and form partnerships with different offices across campus, modeling the behavior we want our students to exhibit as professionals.

\section{Incorporate Social Justice}

The idea of incorporating social justice into coursework or programs entails recognizing the multiple forms of oppression that exist and taking action to interrupt the cycles of oppression (Cooke et al ., 2016). This means being unafraid to bring social justice issues into the classroom and to have discussions of how LIS possesses a latent obligation towards social progress. This includes background research on any applicable oppressed group(s) so that we have a full picture. Simply, a social justice approach is not merely concerned with how to serve homeless populations, but also with locating and dismantling factors that contribute to homelessness. Incidentally, a discussion of homelessness affords a useful example of the care necessary in the incorporation of social justice praxis into the classroom. To look at homelessness as a problem to be fixed through temporary housing, job training, literacy outreach, or any other interventionist undertaking reifies deficit-based approaches to these issues. Doing so suggests that these communities are neither keenly aware of their own oppressions, or 
are incapable of effectively organizing and transcending their situations independent of an outside entity. Such approaches presume that one group of people knows what is best for another group of people. The group giving the advice or suggesting a change almost always does so from a position of outsider privilege. They see a problem that they have either allegedly overcome or have simply avoided experiencing altogether and offer suggestions that do not account for the aforementioned cycles of oppression.

With this in mind the type of social advocacy we imagine at The Knowledge School is one that is built by those communities that are typically historically marginalized to both make their voices not simply heard, but amplified and echoed indefinitely. Librarianship is an inherently service-oriented profession, but what often occurs is an inward and insular look into how staff might be more engaged in their own service work. A shift towards social advocacy would prepare students to be information professionals who understand the limitations of their profession to effect change from an external, top down approach. It would instead implore them to seek out community needs and then shift their praxis to address such desires.

In order to seek out community needs students must develop an awareness of multicultural dynamics. Allard, Mehra, and Qayyum (2007) offered tools to help build multicultural awareness, including recognizing which populations that are served may be marginalized and the means to organize and supply information to them. For example, the way information is shared in an indigenous community may vary greatly from a typical white community. Moreover, archives have often retained the artefacts of indigenous communities and now face ethical questions when said communities request the right to have their belongings repatriated. In this moment, archives must reflect on their role as a presumptively "good" entity and understand that their work may not be desired by certain 
populations, or, in fact, was done without the consent of certain group. Forward thinking librarianship contends that archives can do their work by not claiming authority over archival interpretation, but serving merely as a repository, while allowing indigenous folks to control their narratives. Jenkins et al. (2017) imagine this as an endeavor of tribesourcing. However, merely giving voice to marginalized communities within cultural heritage spaces is not enough, practitioners and institutions must further realize and emphatically acknowledge that American systems were built to uphold the structure of white supremacy and therefore benefit white people. We must teach our students to critically think about and analyze these issues and how they play out locally.

As one might imagine, this obviously puts LIS instruction at odds with a maxim of best practices, as it suggests situational, needs-based approaches to how students work with diverse and divergent communities. Even in the most idealized of settings such an approach cannot be taught within a purely lecture-based instructional space. What is needed is a method that connects students with communities and allows them to explore engagement and praxis within real world contexts that produce their oft desired skills. Further these skills need to be malleable and context-oriented, so students can evolve and alter their skills as a given situation demands of them. While it is hardly a perfect solution, we believe in earnest that the pedagogical trappings of the service-learning model offer such opportunities.

\section{Service-learning and Social Advocacy}

Service-learning is a way to get students out in the community by working on projects that “address human and community needs" (Jacoby, 1996, p. 5). These experiential education experiences should benefit both the students and the community partner, ensuring that education is happening as a service is being provided (Furco, 1996). service-learning is an ideal way to get them to engage in 
experiences beyond the classroom and connect them to theories, concepts, or frameworks learned in class. It also illustrates to students the complexities that arise when working within communities of which they are not a member.

Instructors should not just throw students into a community without preparing them, especially if the students will be working with marginalized populations, as it could recreate the oppression for the people being served. Hackman (2005) offered a framework that outlined five components of social justice education that can be incorporated into service-learning. The framework includes ensuring students have a full, complex understanding of the history and issues surrounding a population. This understanding comes, in part, from incorporating non-dominant sources. Examples of non-dominant sources may include articles or books written by people of color, or blogs and other web-based resources by members of the LGBTQIA+ community, and zines from feminist and advocacyoriented organizations. Hackman also discussed critical thinking and analysis, multicultural awareness, and tools for action and social change in the framework. Any moves to account for social advocacy that acknowledge and adhere to meaningful diversity work must do so with the goal of centering and empowering those marginalized populations. As Ahmed (2012) noted, we should be cautious of diversity work that serves to fill a checkbox of "doing" diversity while simultaneously doing little to actually produce systematic change and equity for marginalized populations. This type of detached and performed approach only works to affirm that individuals with privilege are capable of acknowledging that oppressions exists and, in doing so, become good champions for diversity only in theory. Personal reflection is the final component of Hackman's model and is essential to the servicelearning process. service-learning requires a reflective component that should be a structured part of the course. This reflection piece is vital so students have the opportunity to process what they have 
learned outside of the classroom and think about how this interacts with what they've learned inside the classroom. In addition, it helps them to start to understand how their experience may have challenged their assumptions and beliefs.

For example, a graduate-level course on assessment taught by one of the authors requires students to complete a real-life assessment project in an LIS organization. The program or service that is assessed must focus on a traditionally marginalized population. Incorporating a project like this gets students out in their community and can open their eyes to groups of people they live near but of which they are unaware. Students are required to reflect in a journal as a graded part of the course.

Alternatively, the other author of this chapter teaches a course focusing on information literacy and technology use for undergraduate students, both within and outside of the LIS field. While the course traditionally requires that students create documents like annotated bibliographies to build towards research papers, the author instead exchanges a research paper for a social advocacy product that asks students to apply information literacy skills to complex social concerns. In the process of doing so, students come to recognize their own inherent privileges or oppressions as they relate to the deceptively objective task of gathering research. The students then provide their final products: webinars, short documentaries, library guides, how-to guides, and even art-based projects that speak from a place of thoughtful research, but, more crucially, speak with their intended communities, not for/over/against them. In past iterations of the course, students came to realize preconceived notions about the world in a new and more socially-aware manner. For example, students have learned that food deserts, despite their name, tend to appear in heavily populated areas. Similarly, students have come to understand that it is hard for LGBTQIA+ folks to get equitable healthcare information and that 
when it comes to advocating for legal representation, First Nations populations often find themselves at odds with antiquated and harsh legal barriers.

In both examples, adding a social justice angle to a project required offering the students resources on social justice education and how that looks in the LIS field. Students had to learn skills to benefit them professionally, while simultaneously noting that such benefits were far from universal. Throughout the process, students were consistently asked to consider their privilege and to de-center themselves. The act of de-centering means we teach students how to research, explore, and learn to see what the needs of a particular population are, not assume they have the answers or that they can get the answers out of a book. It requires going out into the community and interacting with the people we're serving. They must understand how their privilege (their membership in a dominant group, such as male, or white, or their socioeconomic status) may play into those interactions. Further, they learned to be aware that such privileges are often carried around in what McIntosh (1988) calls an invisible knapsack of privilege, with such privileges going unaccounted for until a marginalized group points them out.

\section{Conclusion}

In summary, we hope to instill in graduates the ability to effectively and knowledgeably serve all their stakeholder communities. These graduates will benefit from a program that focuses on them, advocates social justice issues, and provides service-learning opportunities. This will allow them to build strong community connections and partnerships; develop an outward gaze and decenter themselves when working with people and groups that are culturally, socially, or otherwise different from them; and build the world their communities deserve. 


\section{References}

Ahmed, S. (2012). On being included: Racism and diversity in institutional life. Durham, NC: Duke University Press.

Allard, S., Mehra, B., \& Qayyam, M. A. (2007, Summer). Intercultural leadership toolkit for librarians: Building awareness to effectively serve diverse mulit-cultural populations. Education Libraries, 30(1), 5-12.

Cooke, N. A., Sweeney, M. E., \& Noble, S. U. (2016). Social justice as topic and tool: An attempt to transform an LIS curriculum and culture. The Library Quarterly, 86(1), 107-124.

Furco, A. (1996) Service-learning: A balanced approach to experiential education. Expanding boundaries: Service and learning, 1-6.

Great Schools Partnership. (2014). Student-centered learning. Retrieved from https://www.edglossary.org/student-centered-learning/

Hackman, H.W. (2005). Five essential components for social justice education. Equity \& Excellence in Education, 38(2), 103-109. http://www.doi.org/10.1080/10665680590935034

Hankins, R., \& Juárez, M. (2016). Where are all the librarians of color? The experiences of people of color in academia. Sacramento, CA: Library Juice Press.

Jacoby, B. (1996). Service-learning in today's higher education. In B. Jacoby (Ed.) Service-learning in higher education (pp. 3-15). San Francisco, CA: Jossey Bass.

Jenkins, J. L., Quiroga, G., Quiballo, K., Peterson, H. A., \& Sorrell, R. (2017). Rural and small libraries: The tribal experience. In Rural and small public libraries: Challenges and opportunities (pp. 203218). Emerald Publishing Limited. 
McIntosh, P. (1988). White privilege: Unpacking the invisible knapsack. Race, class and gender in the United States: An integrated study, 4, 165-196.

National Center for Transgender Equality. (2017). South Carolina. Retrieved from https://transequality.org/documents/state/south-carolina

Strangman, N., Rappolt, G., Rose, D. H., \& Meyer, A. (2002). Teaching every student in the digital age: Universal design for learning. Alexandria, Va: Association for Supervision and Curriculum Development. 